\title{
АНАТОМІЧНЕ ОБГРУНТУВАННЯ ОПТИМАЛЬНОГО ОБ'ЄМУ І МЕТОДУ ОПЕРАТИВНОЇ КОРЕКЦІї НЕДОСТАТНОСТІ КЛУБОВОГО ОТВОРУ
}

๑о.в. Біктіміров

\author{
Вінницький національний медичний університет ім. М.І. Пирогова
}

РЕЗЮМЕ. В експерименті на 40 тваринах проведена комплексна оцінка морфофункціональних структур ілеоцекального відділу при застосуванні нового способу хірургічної корекції недостатності клубового отвору. КЛЮчОВІ СЛОВА: клубовий отвір, морфологічні зміни, математичне моделювання.

Вступ. Проблема розробки оптимальних реконструктивних оперативних втручань $є$ актуальною в сучасній хірургії. Особливо це стосується патології шлунково-кишкового тракту. На сьогодні як у дорослих, так і у дітей досить поширеними залишаються захворювання, пов'язані 3 розладами замикальної функції клубового отвоpy $[1,2,3,4,5]$.

Недостатність клубового отвору, як і формування загальновідомих тонко-товстокишкових анастомозів, після правобічної геміколектомії, призводить до порушення пасажу кишкового вмісту, його швидкості, парціальності, циклічності надходження з тонкої кишки в товсту. Поряд 3 цим ілеоцекальний відділ є місцем інтенсивного розмноження мікроорганізмів, головним чином представників анаеробної мікрофлори [6]. Основна складність при розробці реконструктивних операцій на кишечнику з відновленням функцій втрачених відділів полягає не тільки у відмінностях діаметрів анастомозувальних ділянок, а також більшою мірою в специфічних особливостях їх функцій, мікрофлори, судинного забезпечення. Найбільш сконцентровані дані проблеми у відділі ілеоцекального кута, що вимагає цілеспрямованого відтворення бар'єру, максимально наближеного до нормального між тонкою і товстою кишкою у вигляді клапану [7].

Існуючі способи формування анастомозів [1, 8, 9] повною мірою не відповідають вимогам фізіологічних взаємовідношень кишкової трубки. На сьогодні не існує оптимального способу оперативного лікування шляхом відновлення багатьох умов нормального функціонанування прооперованого відділу об'ємної форми складових частин ілеоцекального відділу та пасажу кишкового вмісту.

Мета дослідження - морфофункціональна оцінка способу хірургічної корекції недостатності клубового отвору, розробленого на основі математичного моделювання.

Матеріал і методи дослідження. Робота виконана на 40 собаках. Утримання тварин та маніпуляції проводили відповідно до положень
"Європейської конвенції про захист хребетних тварин, які використовуються для експериментальних та інших наукових цілей" (Страсбург, 1985 р.), "Загальних етичних принципів експериментів на тваринах", ухвалених Першим Національоним конгресом з біоетики (Київ, 2001 р.).

Комітетом з біоетики Вінницького національного медичного університету ім. М.І. Пирогова встановлено, що дослідження не суперечать основним біоетичним нормам експериментальних досліджень (протокол № 7 від 25 січня 2006 р.).

Загальні зміни в структурних елементах кишки виявляли за допомогою загальногістологічних і гістохімічних методик дослідження. Для виявлення ультраструктурних змін в паренхіматозно-стромальних елементах клубової кишки застосовували електронну мікроскопію.

3 метою оцінки функціонального стану кишки досліджували швидкість пасажу кишкового вмісту, моторно-евакуаторну функцію, погодинну кількість надходження хімусу, а також ступінь мікробної колонізації у тварин при різних варіантах хірургічних реконструктивних втручань. Ступінь рефлюксу кишкового вмісту в термінальну частину клубової кишки вивчали методом іригографії.

Для обгрунтування необхідності відновлення складових частин ілеоцекального відділу (губ, вуздечок, ампули і передампулярного звуження) в розробці оптимального варіанту корекції недостатності клубового отвору застосовано метод математичного моделювання, який базується на основних законах гідродинаміки. Виходячи з основних законів гідродинаміки (Бернулі, Паскаля, Пуазейля, нерозривності струменя і інше), порожнисті органи травної системи можна представити як трубку, в якій одна частина відрізняється від іншої не тільки об'ємною формою, а й шириною її просвіту на різних ділянках. Для полегшення розуміння і проведення певних розрахунків припустимо, що стінка кишкової трубки жорстка, без гофрування та складчастості, а кишковий вміст як ідеальна рідина, тобто без наявності густини, тертя та ін. Метода- 
Оәляди літератури, оригінальні дослідження, погляд на проблему, короткі повідомлення, замітки з практики

ми електрогідродинамічних аналогій були визначені параметри відновлюваних зон термінальної частини клубової кишки, шляхом висічення серозно-м'язових клаптів з наступним зшиванням країв рани (передампулярне звуження), довжину губ клапана (занурювання термінальної частини клубової кишки з стінкою сліпої в її просвіт на відповідну глибину) та поглиблення вуздечок, формування поперечної складки за рахунок стінки сліпої кишки, при недостатності отвору клубової кишки. Даний спосіб захищений патентом України на винахід "Спосіб баугінопластики" Патент на винахід 35741 А Україна, МПК6 А61 В17/00 № 98041799 опубліковано 16.04.2001 р. Бюл. № 3.

Цифрові дані вносили в розрахункову таблицю, створену на базу програмного пакета "STATISTICA 55" (належить ЦНIT ВНMУ, ліцензійний номер AXX R 910 A 374605 FA).

Результати й обговорення. При дослідженні швидкості просування кишкового вмісту, тобто фіксація часу від моменту поїдання міченої страви до повного виділення підфарбованого калу через 30 діб після операції коливалась від 17 год 50 хв до 20 год 37 хв, що в середньому становило 19 год $(18 \pm 44,3)$ хв ( $p>0,05)$. У кінці дослідження (180 діб) швидкість переміщення кишкового вмісту коливалась від 18 год 37 хв до 19 год $(56 \pm 30,1)$ хв ( $>0,05)$.

При рентгенологічному дослідженні моторно-евакуаторної функції шлунково-кишкового тракту через 180 діб після оперативного втручання було встановлено, що перші порції барію досягали сліпої кишки (СК) через $(190,0 \pm 17,17)$ хв і евакуація його з тонкої кишки (ТК) закінчувалась і середньому через $(270,0 \pm 53,1)$ хв. При проведенні іригоскопії було встановлено, що як в ранні строки після операції (30 діб), так і в кінці дослідження (180 діб) рефлюксу барію з СК в ТК не відмічалось.

Кількість погодинного надходження хімусу в СК також залишалась однаковою як в ранні, так і в віддалені строки після реконструктивної операції за власним способом. Так, через 30 діб перші порції хімусу виділилися з фістули в СК через 2 години $(31 \pm 4,0)$ хв, при цьому виділилось $(35,5 \pm 0,7)$ мл. Виділення хімусу з фістули СК продовжувалось протягом дев'яти годин як через 30, так і через 180 діб після операції.

При засіванні кишкового вмісту клубової кишки через 180 діб після операції кількість мікроорганізмів склала 1×105 КУО на 1 гр вмісту, що практично відповідало нормі, тобто такому рівню, як і у контрольних тварин.

Антирефлюксну функцію клапанного апарату отвору клубоковї кишки вивчали на ізольова- них препаратах. При цьому було встановлено, що повітря з відрізка клубової кишки починало виділятися при величині тиску 75,8-104,5 кПа (5579 мм рт.ст.), що свідчило про достатню антирефлюксну функцію.

Макроскопічно ампула і передампулярне звуження зберігається у всі терміни спостережень. При розрізі стінки кишки, вуздечки, губи і щілиноподібний ОКК добре виражені як в ранні, так і віддалені строки.

Мікроскопічно через три доби після операції в термінальному відділі клубової кишки, зоні анастомозу та сліпій кишці спостерігались розлади гемодинаміки, набряку та запальні зміни.

Слизова оболонка клубової кишки набрякла, помірно гіперемійована. Ворсинки покриті циліндричним епітелієм. На верхівках ворсинок епітелій вогнищево відсутній. Стовпчасті епітеліоцити ворсинок часто без посмугованої облямівки. Кровоносні судини власної пластинки розширені, виповнені еритроцитами. Серед епітеліоцитів виявляють поодинокі келихоподібні клітини. В стромі виявляють лімфоцити, макрофаги, які щільно прилягають до епітеліальних клітин. Макрофаги активно поглинають мікробні тіла. В цитоплазмі активованих макрофагів спостерігають деструктивно змінені мікроорганізми. Серед лімфоцитів переважають В-лімфоцити, 3 добре розвинутою ендоплазматичною сіткою.

Волокнисті структури підслизової основи набряклі. В вогнищах венозного повнокров'я і набряку відмічали набухання колагенових волокон з появою метахромазії. М'язова оболонка представлена шарами гладких міоцитів з циркулярним і повздовжнім розташуванням. Між волокнами спостерігають прошарки сполучної тканини та кровоносні судини. Останні гіперемійовані.

Серозна оболонка утворена пухкою сполучною тканиною і кровоносними судинами, яка покрита мезотелієм. Вогнищево мезотелій деструктивно змінений.

В структурах новоутвореного клапанного апарату та слизовій оболонці сліпої кишки відмічають ідентичні зміни, що і в паренхіматозно-стромальних елементах клубової кишки.

На 7 та 14 добу після реконструктивного втручання в структурах, що досліджувалися, відмічається зменшення розладів гемодинаміки та наростання регенераторно-пристосувальних змін, вираженність яких зростає на 14 добу. Слизова оболонка термінальної частини клубової кишки та ділянки анастомозу звичайної структури. В стовпчастих епітеліоцитах ультраструктурні зміни вказують на посилення регенераторних процесів. В епітеліоцитах доб- 
Огляди літератури, оригінальні дослідження, погляд на проблему, короткі повідомлення, замітки з практики

ре виражена ендоплазматична сітка з великою кількістю рибосом. Ядра клітин активовані. Цистерни ендоплазматичного ретикулума розширені. Мітохондрії гіпертрофовані.

М'язова та серозна оболонки морфологічно незмінені. Через 30 діб після відновлення складових ілеоцекального клапана в паренхіматозно-стромальних елементах комплексу, що досліджується, спостерігаються поверхневі зворотні зміни. В термінальному відділі клубової кишки та ділянці анастомозу слизова оболонка звичайної структури 3 добре вираженими ворсинками. Стовпчасті війчасті епітеліоцити ворсинок циліндричної форми. Вогнищево мікроворсинки відсутні. Серед всіх клітин незначна кількість келихоподібних клітин. Вміст нейтральних та кислих глікозаміногліканів в келихоподібних клітинах дещо знижений.

Власна пластинка слизової оболонки утворена пухкою сполучною тканиною та системою гемо-лімфокапілярів. Гемокапіляри звичайного кровонаповнення. Лімфокапіляри не розширені і без ознак лімфостазу. У власній пластинці відмічається скупчення лімфоїдних агрегатів. У деяких ділянках лімфатичні інфільтрати проникають в підслизову основу. М'язова пластинка представлена двома шарами гладком'язових клітин. Підслизова основа без ознак набряку. В ній виявляють колагенові, аргірофільні волокна та численні кровоносні і лімфатичні судини. Стінки кровоносних судин звичайної будови. В просвітах кровоносних судин спостерігають еритроцити, які розташовані ексцентрично. Периваскулярно локалізуються лімфоцити і макрофаги. Вогнищево зустрічаються лімфоїдні фолікули. М'язова оболонка всього відділу клубової кишки не гіпертрофована. Між м'язовими шарами відмічаються прошарки сполучної тканини та кровоносні судини. Серозна оболонка морфологічно не змінена.

Через 90 та 180 діб після відновлення складових елементів клубового отвору в досліджуваних структурах патологічних змін не виявлено.

Поверхня слизової оболонки і крипт клубової кишки покрита одношаровим епітелієм. Ворсинки покриті одношаровим епітелієм з облямівкою. у базальних відділах переважає епітелій без облямівки. Підслизова основа представле-

\section{ЛІТЕРАТУРА}

1.Витебский Я.Д. Очерки хирургии илеоцекального отдела кишечника. М.: Медицина, 1973. - 111 с.

2.Ормантаев К.С., Архаров Н.Н., Агепов Р.Р. Клинико-функциональная диагностика и хирургическое лечение недостаточности илеоцекального запирательного аппарата у детей // Дет. хирургия. - 1999. - № 1. - C. 6-9. на сполучнотканинними волокнами і значною кількістю кровоносних судин. Останні нерівномірного кровонаповнення.

При ультраструктурному дослідженні на мікроворсинках виявляється глікокалікс, який має вигляд сітки, утвореної із тонких волокон. Ентероцити щільно прилягають один до одного. Між епітеліоцитами виявляють келихоподібні клітини з численними секреторними гранулами. Серед епітеліоцитів в слизовій оболонці виявляють скупчення переважно В-лімфоцитів. У клітинах добре розвинута ендоплазматична сітка, яка щільно контактує з мітохондріями і ядром, що свідчить про високу функціональну активність. М'язова та серозна оболонки клубової кишки морфологічно незмінені.

Слизова оболонка сліпої кишки утворена одношаровим циліндричним епітелієм, власною та м'язовою пластинками. Відмічають численні крипти. У власній пластинці виявляють скупчення лімфоцитів. Підслизова основа представлена пухкою сполучною тканиною, кровоносними судинами та лімфоїдними скупченнями. У деяких тварин в цей термін спостережень виявляли потовщення м'язової пластинки слизової оболонки. М'язова і серозна оболонки сліпої кишки патологічно не змінювались.

Висновки. 1. Застосування власного способу баугінопластики, розробленого на принципах математичного моделювання при недостатності клубового отвору, нормалізує пасаж кишкового вмісту, надійно профілактує розвиток рефлюксу хімусу, мікробної колонізації клубової кишки та термінального ілеїту.

2. Паренхіматозно-стромальні елементи кишечнику відновлюють свою структуру на 7-14 добу після оперативного втручання.

3. Віддалені результати досліджень (180 доба) підтвердили надійність даного способу хірургічної корекції недостатності клубового отвору.

Перспективи подальших досліджень. Розроблений оптимальний спосіб відновлення структурної форми складових частин ілеоцекального відділу (губ, вуздечок, ампули і передампулярного звуження) при недостатності клубового отвору слід рекомендувати для впровадження в клінічну практику.

3. Гаїна Н.І. Ембріогенез кишкової трубки // Тези доп. Всеукр. наук. конф. "Акт. питання клін. анат. та операт. хірургії” // Клін. анат. та операт. хірургія. - 2004. - T. 3, № 3. - С. 67.

4. Яценко С.М. Вплив окремих антигемостатиків на віддалені результати хірургічного лікування хворих на рак ободової кишки залежно від ступеня ди- 
Огляди літератури, оригінальні дослідження, погляд на проблему, короткі повідомлення, замітки з практики ференціації та форми росту пухлин // Клін. хірургія. 2004. - № 8. - C. 48-52.

5.Парфенов А.И. Боль в правой позвоночной области в практике терапевта // Терапевт. архив. 2006. - Т. 78, № 2. - С. 5-10.

6. Фадєєнко Г.Д., Кушнір І.Е. Дисбіотичні порушення кишечнику і шляхи їх корекції // Сучасна гастроентерологія. - 2006. - № 2. - С. 30-34.

7. Москаленко В.З., Литовка В.К., Веселый С.В. Наложение тонко-толстокишечного анастомоза у детей // Клінічна хірургія. - 2004. - № 4-5. - С. 25-26.

8. Дамбаев Г.Ц., Пекарский В.В., Соснин А.В. Способ пластики илеоцекального перехода. SU 1424803 Al A61 В 17/00 // Открытия. Изобретения. - 1980. № 35. - C. 1 .

9. Яремчук А.Я., Круцяк В.Н., Бойда А.И. Способ дислокации илеоцекального отдела кишечника и восходящей ободочной кишки // Вестн. хирургии им. И.И. Грекова. - 1989. - № 1. - С. 126-127.

\title{
AN ANATOMIC SUBSTANTIATION OF OPTIMAL VOLUME AND METHOD OF OPERATIVE CORRECTION OF ILIAC FORAMEN INSUFFICIENCY \\ @O.V. Biktimirov

\author{
Vinnytsia National Medical University by M.I. Pyrohov
}

SUMMARY. A combined estimation of the morphofunctional structures of the ileocecal part while using a new way of surgical correction of iliac foramen insufficiency was done in the experiment on 40 animals.

KEY WORDS: iliac foramen, morphofunctional changes, mathematical modelling.

УДК612.751-02:612.89-092.9

\section{ОСОБЛИВОСТІ СТРУКТУРИ ТА ХІМІЧНОГО СКЛАДУ ПЛЕЧОВИХ КІСТОК У БІЛИХ ЛАБОРАТОРНИХ ЩУРІВ-САМЦІВ З РІЗНИМ ТИПОМ АВТОНОМНОГО ВІДДІЛУ НЕРВОВОї СИСТЕМИ}

ФА.Л.Білик

\author{
Тернопільський державний медичний університет імені І.Я. Горбачевського
}

РЕЗЮМЕ. У популяції білих безпородних лабораторних щурів-самців визначали тип автономної нервової системи, відносно якого проводили сортування тварин. У сформованих таким чином групах тварин визначали відмінності макроскопічних показників плечових кісток, особливості будови проксимальної епіфізарної хрящової пластинки, губчастої та компактної речовини діафізарного відділу, кількісного хімічного складу. Проведене дослідження дозволило встановити величини розподілу популяції білих лабораторних щурів-самців залежно від типу автономної нервової системи, та зробити ряд висновків щодо особливості структуризації їх плечових кісток. КЛЮчОВІ СЛОВА: плечова кістка, губчаста речовина, компактна речовина, хімічний склад, автономна нервова система.

Вступ. Історія розвитку знань про структуру та вплив на організм вегетативної нервової системи почалася ще з часів давньої Греції. Тоді ж вперше були спроби пов'язати типи характерів та конституції людини з особливостями взаємодії нервової системи. Згідно з сучасними постулатами, контроль та утримання гомеостазу живого організму здійснюється за рахунок постійної активності симпатичних і парасимпатичних центрів на всіх рівнях сегментарного відділу вегетативної нервової системи, їх диференційованому впливові на клітини, тканини, органи, системи, апарати та організм в цілому залежно від стану даних структур та зміни середовища навколо них [1]. Однак лише в недалекому минулому, разом 3 розвитком космічної медицини, вперше з'явилися спроби практичного використання знань про активність відділів автономної нервової системи [2], домінування одного з них над іншим, чи їх рівноважну активність з метою прогнозу ризиків, адаптаційної можливості конкретного організму в певних умовах. Однак ефективність таких прогнозів потребує формування інформаційної бази про межі компенсаторно-пристосувальних реакцій органів та тканин організмів з різними типами активності автономної нервової системи [3].

Мета дослідження - з'ясувати особливості морфофункціонального стану довгих кісток скелета експериментальних тварин з різними типами вегетативної рівноваги. 